\title{
Evaluation of Liquefaction in Ercis Plain during Van Earthquake
}

\author{
Alper Turan ${ }^{1}$, Hany El Naggar ${ }^{2 *}$, and Ramazan Livaoglu ${ }^{3}$ \\ ${ }^{1}$ Geotecnique, Burlington, Canada \\ $2^{*}$ Dalhousie University, Halifax, Canada \\ ${ }^{3}$ Uludag University, Bursa, Turkey
}

\begin{abstract}
The destructive Van Earthquake that struck eastern Turkey on 23 October 2011 caused significant damages and casualties in the Southeastern Turkey City of Van. This study focuses on the liquefaction occurrences in Ercis Plain, where Irsat and Zilan streams are discharged to Lake Van. The liquefaction potential in this area was studied using various analytical methods. Assessment of liquefaction triggering and estimation of seismic induced settlement and lateral spreading were performed. The results of site specific ground response analyses showed that the ground motions were amplified significantly during the earthquake, which resulted in larger values of Cyclic Stress Ratio (CSR) relative to those estimated using simplified methods. A comparison of analytical results with post liquefaction observations indicates that a proper evaluation of CSR values is imperative for a realistic estimation of liquefaction triggering and post liquefaction deformations.
\end{abstract}

Keywords: earthquake, liquefaction, lateral spreading, settlement

\section{Introduction}

Earthquakes result in massive destruction of buildings and associated loss of lives. The global fatality count from earthquakes continued to rise in the last few decades; several earthquakes resulted in an average of more than 100,000 fatalities per year (e.g. the 2003 Bam Earthquake; the 2004 Sumatra-Andaman Earthquake; the 2005 Kashmir Earthquake; and the 2010 Haiti Earthquake). The destructive Van Earthquake that struck Eastern Turkey near the City of Van on Sunday, 23 October 2011, caused significant damage in the city. Hundreds of buildings collapsed and buried numerous victims under the debris. The earthquake killed 604 people and injured 4,152 people. At least 11,232 buildings sustained various degrees of damage, 6,017 of which were found to be uninhabitable. After the earthquake, around 60,000 people were left homeless. The moment magnitude of the Van
Earthquake, $\mathrm{Mw}=7.2$ (USGS); its epicenter was about 16 kilometers north-northeast of the City of Van, and the focal depth was estimated to be 7.2 $\mathrm{km}$.

Liquefaction is a seismic geotechnical hazard that is driven by the site specific conditions. Liquefaction occurs when saturated and cohesionless soils lose their strength as a result of an increase in pore water pressure, often due to earthquake shaking. Liquefaction can have numerous detrimental effects on natural and manmade structures, including settlement, bearing capacity failure, downdrag on deep foundation elements, lateral spreading, and large-scale slope instability (or flow failure). The factors that affect liquefaction susceptibility include: type and the degree of compaction of the soil, natural water content and plasticity of fines, and the magnitude and duration of the ground motion. Several experimental and analytical studies have been

*Corresponding Author: H.E. Naggar, hany.elnaggar@dal.ca, phone: +1 (902) 494-3904 
conducted to better understand the soil liquefaction potential in both free-field and nearfield soil regions and the effect of soil liquefaction on various types of structures (Ishihara 1993, Liu and Dobry 1995, Norris et al 1997, Finn and Fujita 2002, Ashour and Norris 2003, Rollins et al 2005). Several areas in the City of Van experienced liquefaction hazards, including the low lying delta areas with high ground water table near Town of Ercis, which is located North East of Lake Van.

This study focuses on the seismic liquefaction hazards observed in various areas in Ercis Plain, where Irsat and Zilan streams are discharged to Lake Van. The liquefaction potential in these areas was studied by Özvan et al (2008) using simplified analytical methods. The study comprises the review of geological setup and seismo-tectonic structure of Ercis Plain along with existing subsurface information in the area in the light of the seismic induced geotechnical hazards caused by the Van Earthquake. Based on the existing subsurface information, dynamic soil properties were estimated using an empirical relationship. Subsequently, site specific ground response analyses were performed. The results of these analyses were used in the liquefaction assessment and estimation of seismic induced settlement and lateral spreading that were observed in Ercis Plain. Qualitative and quantitative evaluations were performed based on the results of analyses and post-liquefaction observations. This study presents the application of commonly used analysis approaches to the particular liquefaction occurrences observed in Ercis.

\section{Background}

\subsection{Seismo-tectonic structure}

The seismicity of Eastern Turkey, where City of Van is located, is dominated by northerly movement of the Arabic Plate towards the Eurasian Plate. The most important tectonic feature is high and young topography in the seismically active zone along Zargos-Bitlis Suture resulting from the intercontinental convergence between the Arabic and Eurasians Plates (Dhont and Chorowicz 2006).

The new tectonic regime of Eastern Turkey is well documented in a number of studies (Şengör and Kidd 1979, Şengör and Y1lmaz 1983, Dewey et al 1986, Şaroğlu and Y1lmaz 1986, Y1lmaz et al 1987, Koçyiğit et al 2001). This area is one of the youngest intercontinental collision zones on earth, where the Arabian Plate collides with the Eurasian Plate to form the Turkish-Iranian Plateau, causing movement along the North and East Anatolian Fault zones (Türkelli et al 2003). Figure 1 shows tectonic boundaries and plate motions in Eastern Turkey and surrounding regions that include the City of Van.

The northward motion of the Arabian Plate relative to Eurasia causes lateral movement and rotation of the Anatolian Block to the west,

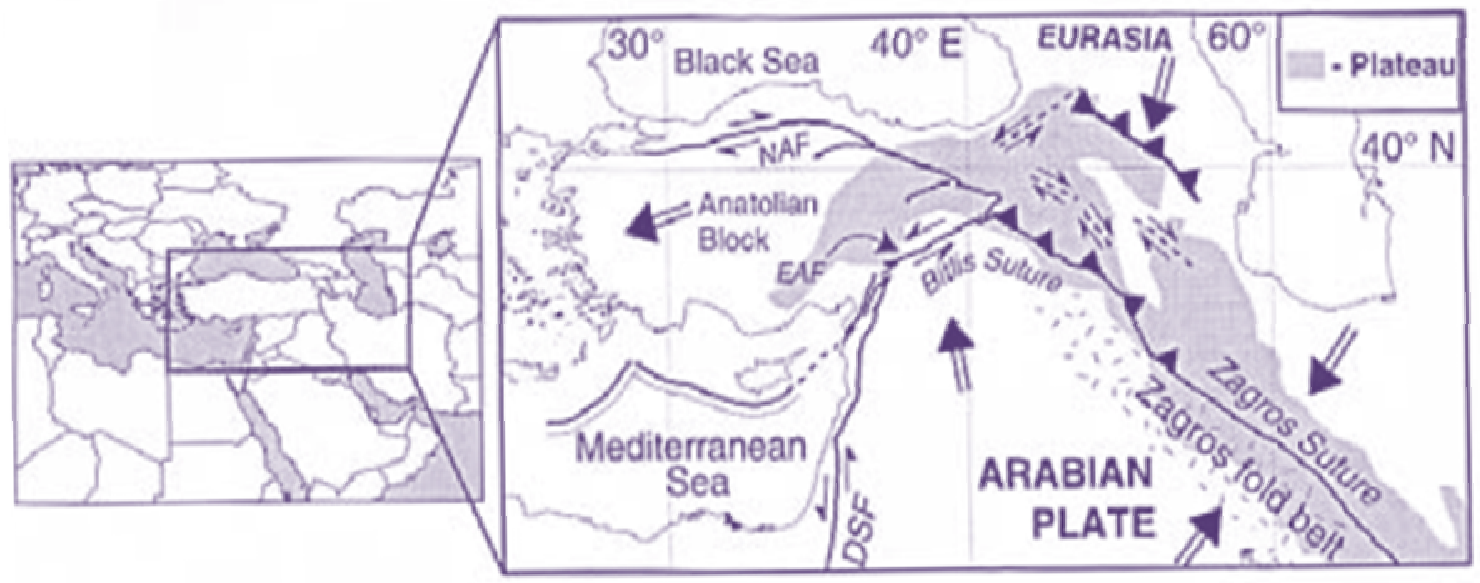

Fig. 1 Tectonic boundaries and plate motions in Eastern Turkey (after Türkelli et al. 2003) 
which manifest itself as a right-lateral strike-slip movement along the North Anatolian fault system (NAF) and the left lateral strike-slip movement along the Eastern Anatolian fault system (EAF) (Dewey and Şengör 1979, Şengör and Kidd 1979, McClusky et al 2000, Türkelli et al 2003). The NAF and EAF have been active since the Miocene (Barka and Kadinsky-Cade 1988) and are associated with large pull apart basins, such as the Karliova Basin located at the junction of these two fault systems (Hempton 1985).

The geodynamic models proposed to the date to explain the Arabia/Anatolia continental collision zone include the continental subduction by Rotstein and Kafka (1982), the Arabian Plate convergence being accommodated entirely by microplate escape by McKenzie (1976), Şengör and Kidd (1979) and Jackson and McKenzie (1988), lithospheric thickening by Dewey et al (1986) and lithospheric delamination by Pearce et al (1990). Türkelli et al (2003) indicates that a combination of these processes formed the seismo-tectonic nature of the area. Figure 2 depicts the seismo-tectonic map of the area.

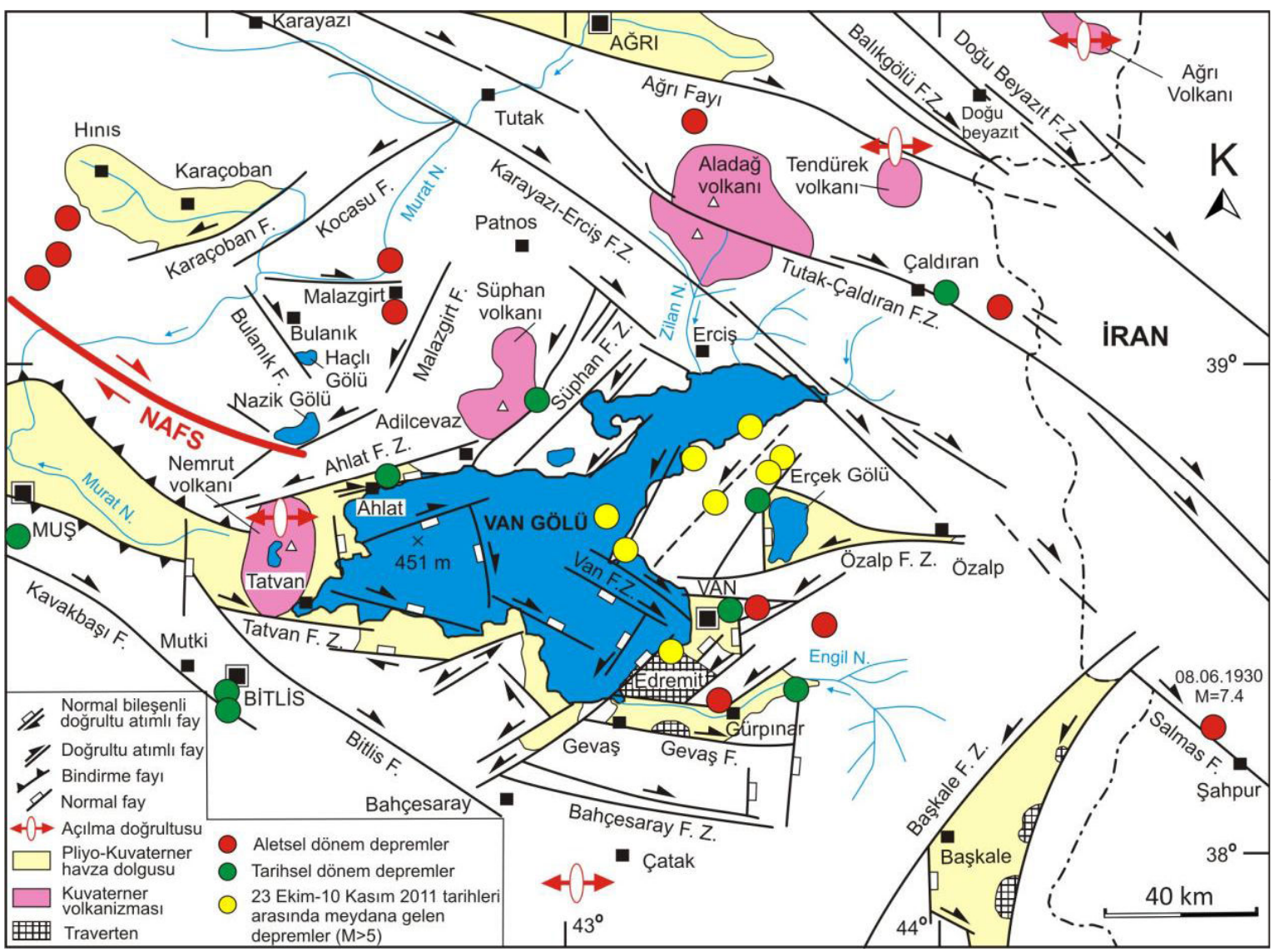

Fig. 2 Seismo-tectonic map of Lake Van (Modified by TMMOB 2011 after Koçyiğit et al 2001)

A comprehensive summary of the historical seismic activities is given in TMMOB-JMO (2011). Figure 3 (a) and (b) depict the locations and magnitudes of historical earthquakes (1990 2011) and October 2011 Van Earthquake main shock and aftershocks, respectively.

\subsection{Geologic conditions}

The areal geology of the Lake Van Basin is described in great detail in TMMOB-JMO (2011). The geologic setup of Lake Van Basin comprises the rock masses and alluvial sedimentations formed during Paleozoic Era. Metamorphic rocks belonging to the Bitlis Massif can be observed south of the basin. The volcanic rocks that are produced by Nemrut and Suphan volcanoes are encountered to the west and east. East of the basin comprises the volcanic rocks and ophiolite compositions belonging to Yuksekova Complex. Figure 4 depicts the geologic map of the general area around Lake Van. 


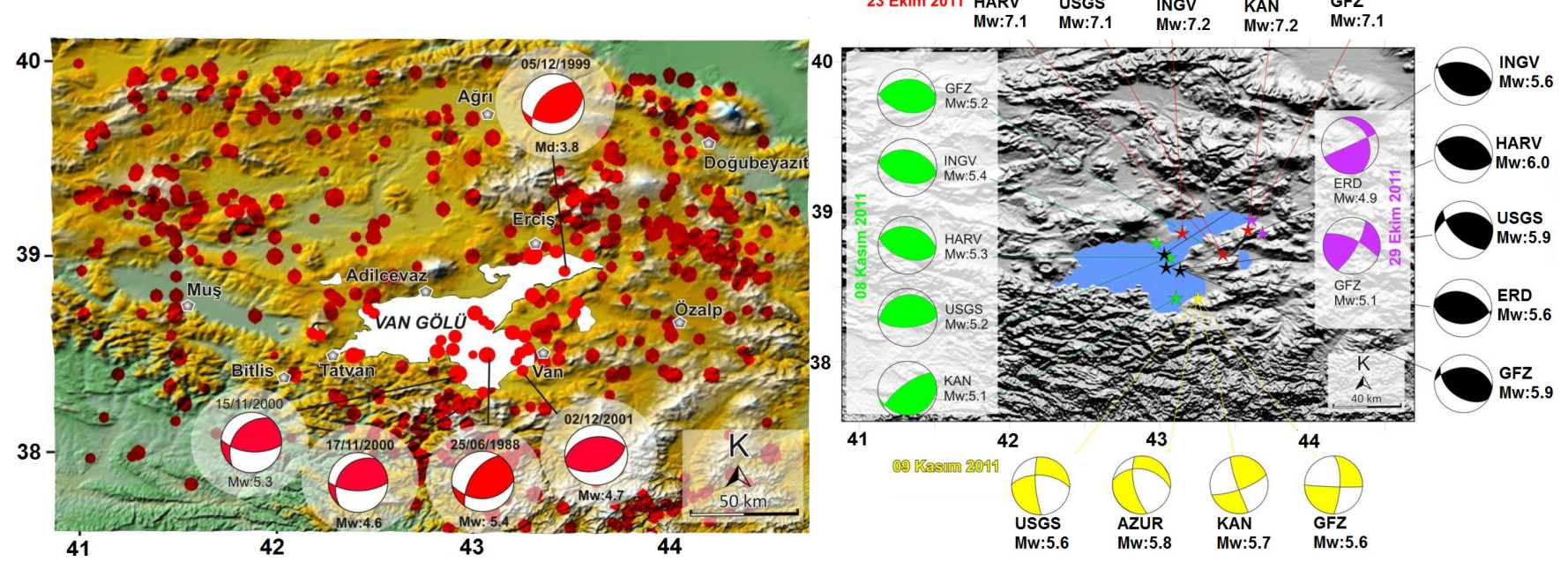

Fig. 3 (a) Locations and magnitudes of historical earthquakes in Lake Van basin between 1990 and 2011, (b) Locations and magnitudes of the October 2011 Van earthquake (main shock) and aftershocks according to various sources (after TMMOBJMO 2011)

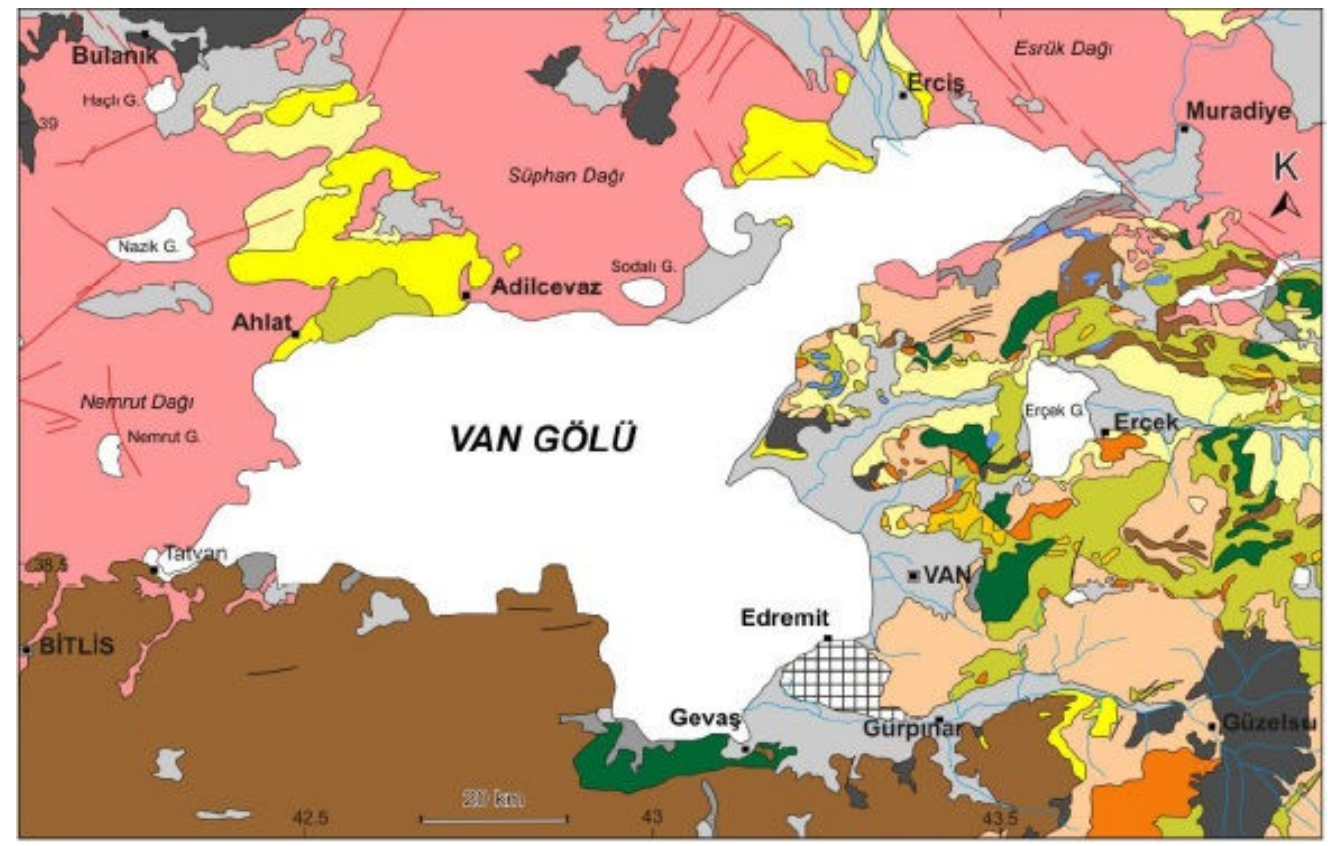

Fig. 4 The geologic map of Van area (after MTA 2002)

Cakar (2010) indicates that the residential areas of the City of Van are located on the lake and river sediment deposits that are composed of clay, sand and aggregates. The rivers that pass through the city center towards Lake Van formed young alluvial deposits. The old city is situated on Eocene period marls near Van Castle and Quaternary period uncemented lake and river deposits near plain areas. These alluvial deposits can be as deep as $150 \mathrm{~m}$ (Acarlar et al 1991). The ground water table is reported to be shallow, ranging between 0 to $5 \mathrm{~m}$.

The Town of Ercis, which is located $100 \mathrm{~km}$ north of City of Van, is located on loose quaternary units. The high ground water levels that are observed in this area and quick spread of residential areas without proper engineering input raised concerns regarding a possible liquefaction hazard in case of an earthquake (Özvan et al 2008). 


\subsection{Strong ground motions}

A detailed evaluation of strong ground motions measured during Van Earthquake and aftershocks were presented in Ceken et al (2011). The strong ground motions of Van Earthquake were obtained from the Turkish Disaster and Emergency Management Presidency (AFAD), who owns and operates a strong ground motion network that comprises 372 stations strategically located throughout the country. The Van Earthquake occurred on 23 October 2011 was recorded by 22 AFAD stations located at distances ranging from
42 to $590 \mathrm{~km}$ from the epicenter. Table 1 gives a summary of measured records. Figure 5 depicts the locations of the stations in the area and maximum accelerations measured by them during the October $23^{\text {rd }} 2011$ Van Earthquake. Due to the proximity to Ercis Plain, Muradiye record was used in liquefaction assessment. Figure 6 depicts the acceleration time histories in N-S, E-W and U-D directions. The peak accelerations were $0.176 \mathrm{~g}, 0.173 \mathrm{~g}$ and $0.08 \mathrm{~g}$ for N-S, E-W and UD components, respectively.

Table 1 Measured accelerations during the October $23^{\text {rd }} 2011$ Van Earthquake (Main Shock)

\begin{tabular}{|c|c|c|c|c|c|c|c|}
\hline \multicolumn{2}{|c|}{ Station } & \multirow{2}{*}{$\begin{array}{c}\text { Type of } \\
\text { Equipment }\end{array}$} & \multicolumn{3}{|c|}{$\begin{array}{c}\text { Measured Accelerations } \\
\text { (gal) }\end{array}$} & \multirow{2}{*}{$\begin{array}{l}\text { Distance } \\
\text { to } \\
\text { Epicenter }\end{array}$} & \multirow{2}{*}{$\begin{array}{c}\text { Vs30 at } \\
\text { the } \\
\text { station } \\
(\mathrm{m} / \mathrm{s}) \\
\end{array}$} \\
\hline City & Town & & $\mathbf{N}-\mathbf{S}$ & E-W & Vertical & & \\
\hline Van & Muradiye & SMACH & 178.5 & 168.5 & 75.5 & 42 & 293 \\
\hline Mus & Malazgirt & SMACH & 44.5 & 56.0 & 25.5 & 95 & 311 \\
\hline Bitlis & City Center & CMG-5TD & 89.66 & 102.24 & 35.51 & 116 & Alluvium \\
\hline Agri & City Center & CMG-5TD & 18.45 & 15.08 & 7.21 & 121 & 295 \\
\hline Siirt & City Center & CMG-5TD & 9.90 & 9.16 & 7.04 & 158 & Alluvium \\
\hline Mus & City Center & CMG-5TD & 10.3 & 6.86 & 4.64 & 170 & 315 \\
\hline Bingol & Solhan & CMG-5TD & 4.58 & 4.19 & 2.46 & 211 & 463 \\
\hline Bingol & Karliova & CMG-5TD & 7.52 & 11.08 & 4.65 & 222 & Hard \\
\hline Batman & City Center & CMG-5TD & 8.29 & 8.58 & 3.74 & 223 & 450 \\
\hline Mardin & City Center & CMG-5TD & 2.00 & 1.90 & 1.58 & 284 & Hard \\
\hline Elazig & Beyhan & CMG-5TD & 1.22 & 1.19 & 0.99 & 289 & Hard \\
\hline Elazig & Palu & CMG-5TD & 2.11 & 1.64 & 1.72 & 307 & 329 \\
\hline Elazig & Kovancilar & CMG-5TD & 1.45 & 1.66 & 1.20 & 313 & Alluvium \\
\hline Erzincan & Tercan & CMG-5TD & 2.37 & 3.43 & 2.26 & 289 & 320 \\
\hline Erzincan & City Center & CMG-5TD & 1.53 & 1.29 & 0.71 & 358 & 314 \\
\hline Bayburt & City Center & CMG-5TD & 1.35 & 1.14 & 1.27 & 327 & Hard \\
\hline Gumushane & Kelkit & CMG-5TD & 1.05 & 0.88 & 1.25 & 378 & Alluvium \\
\hline Sanliurfa & Siverek & CMG-5TD & 2.00 & 3.06 & 0.96 & 378 & Alluvium \\
\hline Malatya & Poturge & CMG-5TD & 0.99 & 0.99 & 0.94 & 405 & Hard \\
\hline Adiyaman & Kahta & CMG-5TD & 2.96 & 2.70 & 1.64 & 437 & Alluvium \\
\hline Adiyaman & Golbasi & CMG-5TD & 1.12 & 0.74 & 0.35 & 521 & 469 \\
\hline K. Maras & City Center & CMG-5TD & 1.74 & 2.18 & 0.96 & 590 & 317 \\
\hline
\end{tabular}




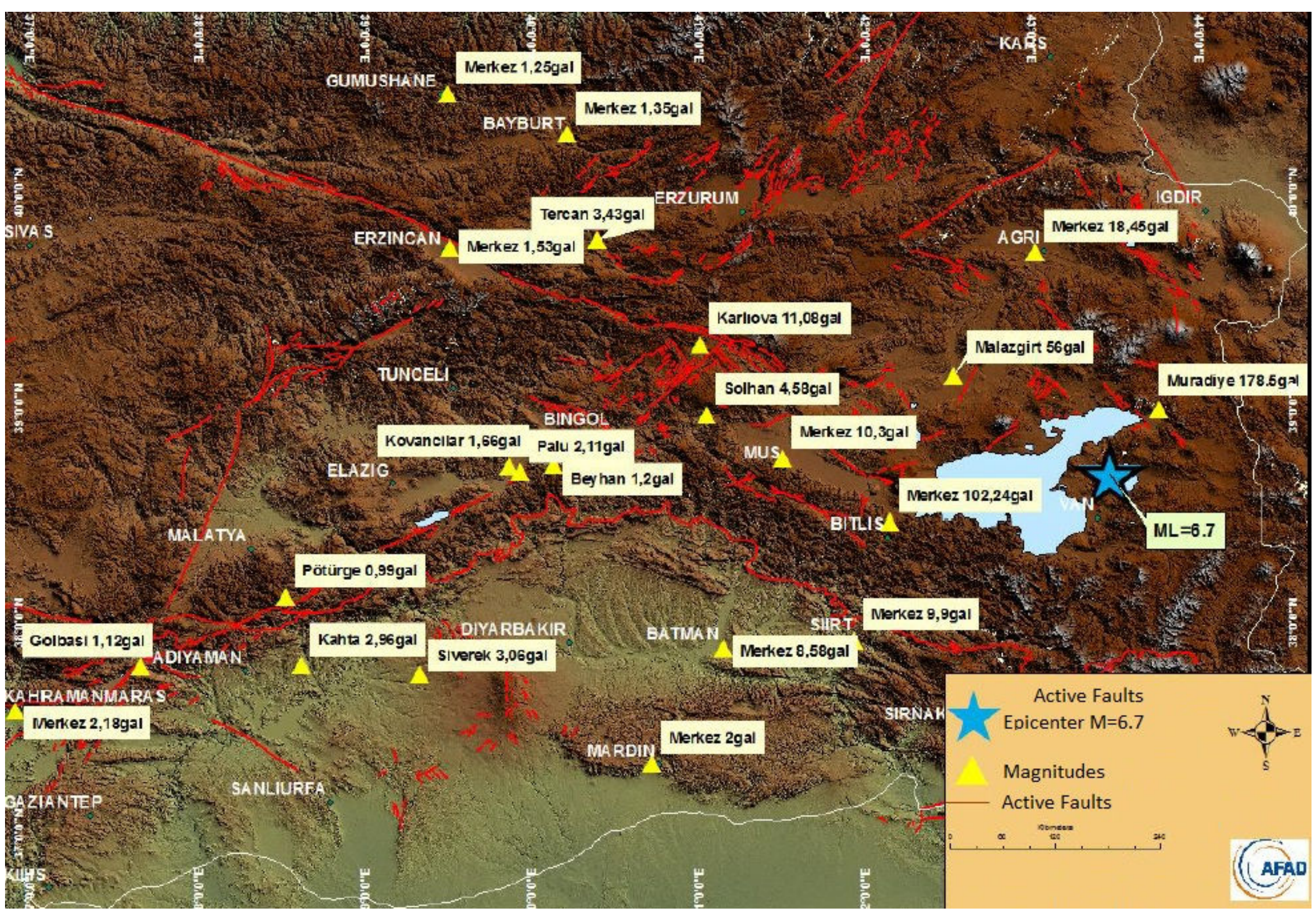

Fig. 5 Locations and maximum accelerations measured by various stations during the October $23^{\text {rd }} 2011$ Van Earthquake (after Ceken et al 2011) 


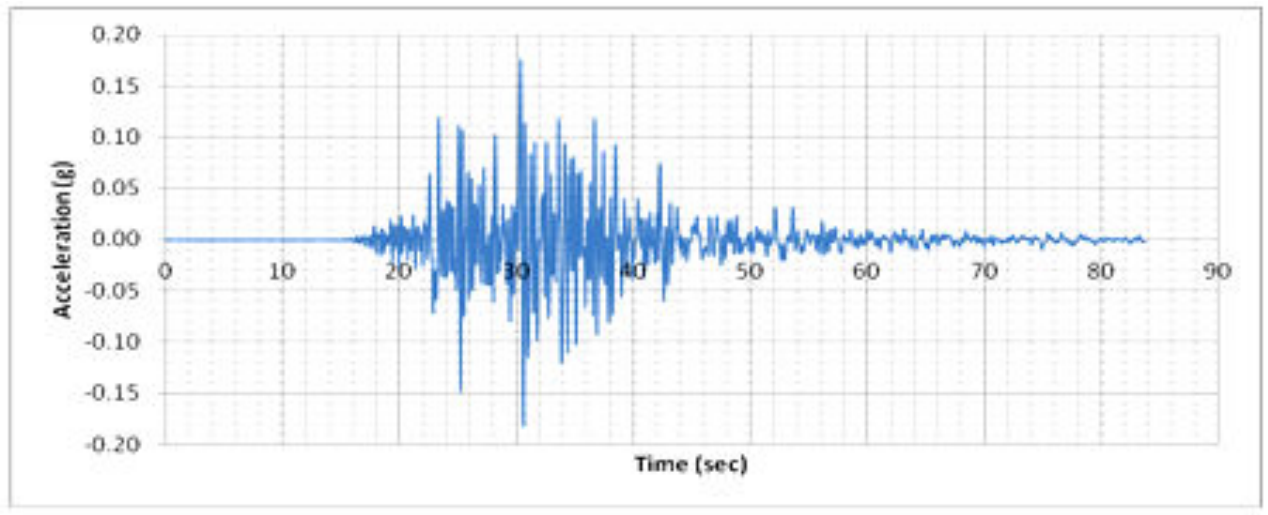

(a)

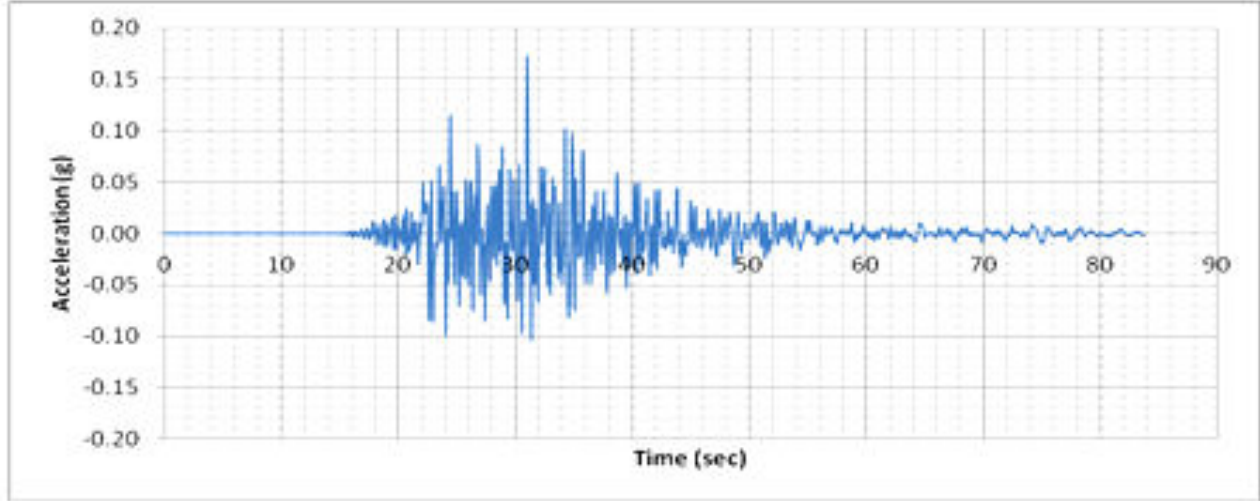

(b)

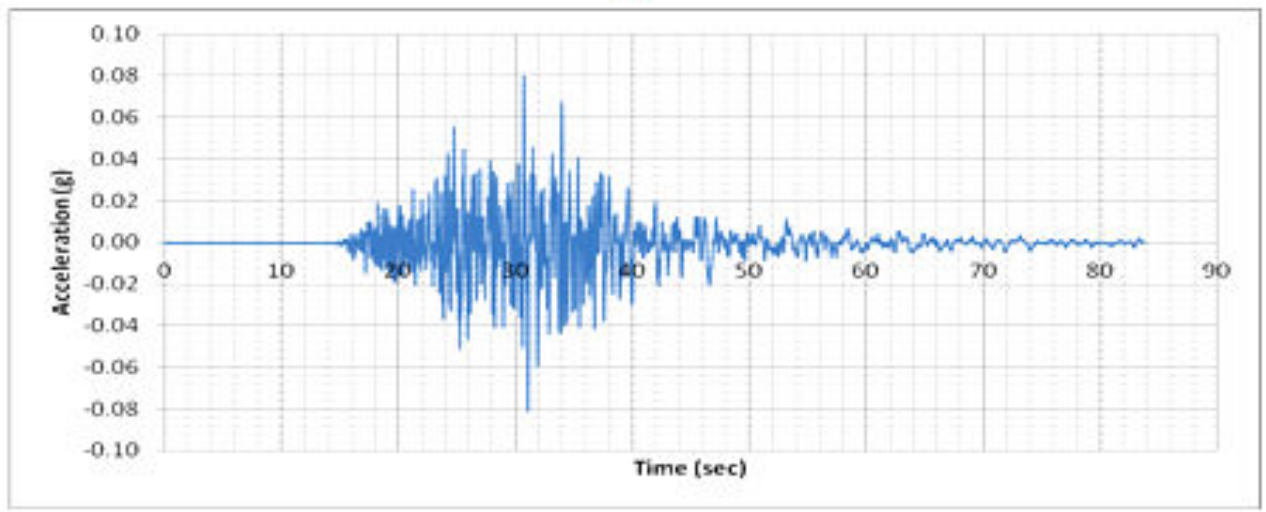

(c)

Fig. 6 Acceleration time histories recorded in Muradiye Station. a North-South component (Peak=0.176g). b East-West component (Peak=0.173g). c Vertical component (Peak=0.08g)

\subsection{Hydrogeology of the area}

There are a number of rivers flowing to Lake Van, including Zilan and İrşat Stream in the vicinity of Ercis Township. These streams form the main drainage system of the Erciş Plain and create a large delta at the north of Van Lake. Özvan et al. (2008) indicated that the depths of groundwater table were ranging between 1 and $12 \mathrm{~m}$ in Erciş.
The direction of groundwater flow was reported to be towards SE and SW and the depth of groundwater table becomes considerably shallower near to the lake. Ulusay et al. (2012) indicated that the groundwater table was generally close to the ground surface near the lake. Fig. 7 depicts the hydrogeological features of Ercis Plain. 


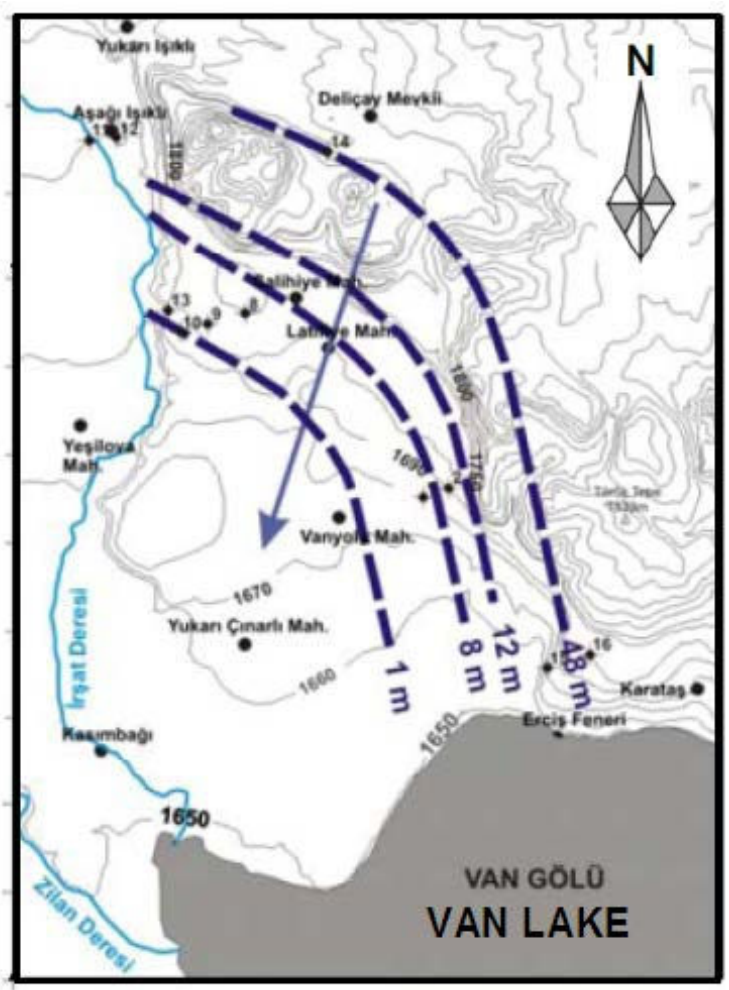

Fig. 7 Hydrogeologic features of Ercis Plain (after Özvan et al 2008)

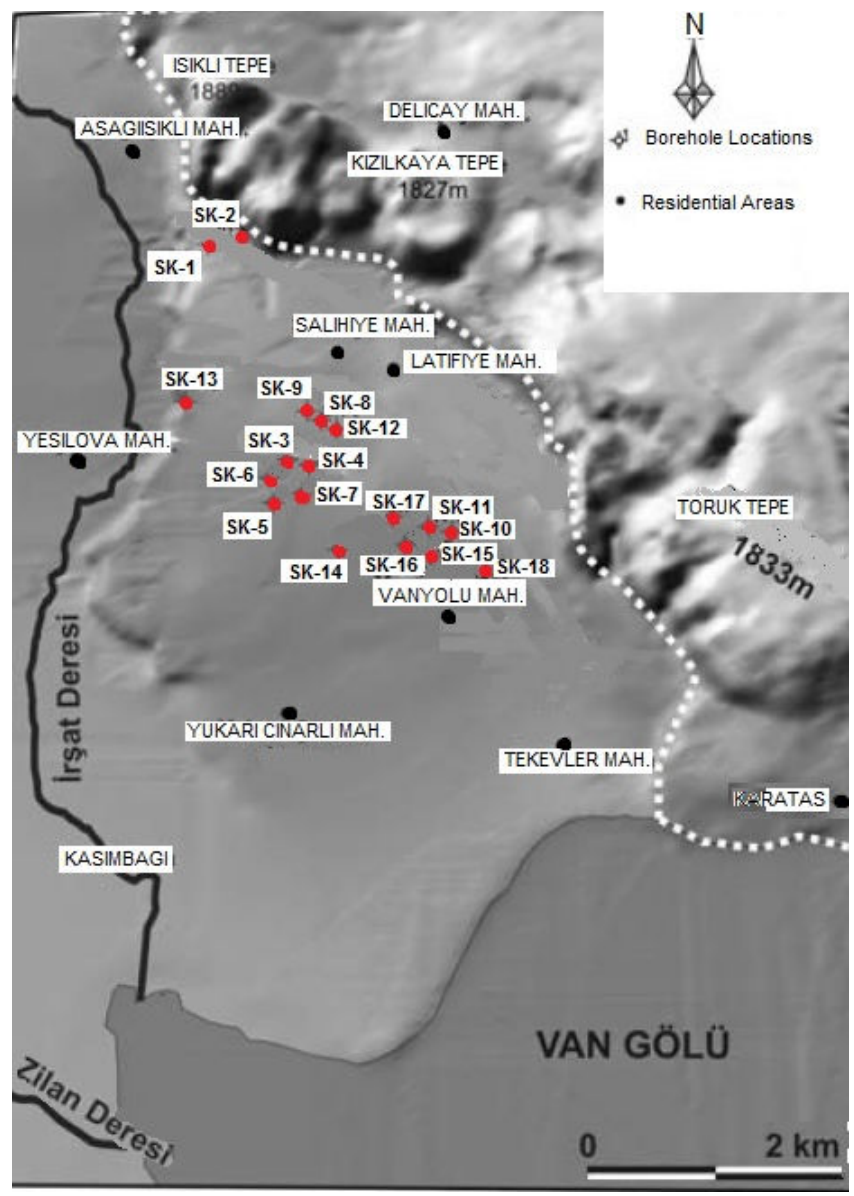

Fig. 8 The location of boreholes (after Özvan et al 2008)

\section{Methodology}

\subsection{Geotechnical conditions}

A detailed description of the geotechnical conditions of Ercis Plain, along with a liquefaction triggering assessment was presented in Özvan et al (2008), which reported 18 boreholes with a layout as shown in Fig. 8.

The grain size distributions of soil samples obtained in the study area were reported by various researchers (Özvan et al 2008, METU/EERC 2011, Ulusay et al 2012, Akyüz et al 2011). Figure 9 summarizes the grain size distributions of the soils that liquefied in Van Earthquake and the ones that were reported by various researchers. The grain size distributions shown in Fig. 9 indicate that most of the data falls within the ranges, where liquefaction hazard are typically expected. Figure 9 also compares the data specific to Ercis plain to the ranges observed in other areas in Turkey, where liquefaction hazards were observed. The average SPT $\left(\mathrm{N}_{1}\right)_{60}$ values presented in Özvan et al (2008) were summarized in Table 2 for top $9 \mathrm{~m}$ of stratigraphy.

Table 2 The average SPT (N1)60 data and ground water levels in the study area

\begin{tabular}{ccc}
\hline Borehole & $\mathbf{( N )}_{\mathbf{1}} \mathbf{6 0}$ & Ground Water Level $(\mathbf{m})$ \\
\hline SK-1 & 11 & 8 \\
\hline SK-2 & 8 & 8 \\
\hline SK-3 & 14 & 3 \\
\hline SK-4 & 10 & 3 \\
\hline SK-5 & 19 & 1 \\
\hline SK-6 & 18 & 3 \\
\hline SK-7 & 19 & 1 \\
\hline SK-8 & 16 & 6 \\
\hline SK-9 & 17 & 6.5 \\
\hline SK-10 & 19 & 4 \\
\hline SK-11 & 16 & 2 \\
\hline SK-12 & 12 & 4 \\
\hline SK-13 & 14 & 7 \\
\hline SK-14 & 10 & 1 \\
\hline SK-15 & 10 & 2 \\
\hline SK-16 & 16 & 1 \\
\hline SK-17 & 10 & 1 \\
\hline SK-18 & 26 & 5.5 \\
\hline
\end{tabular}


The SPT $\left(\mathrm{N}_{1}\right)_{60}$ value for top $9 \mathrm{~m}$ depth averaged from 18 boreholes was 15 . The average SPT $\left(\mathrm{N}_{1}\right)_{60}$ value beyond this depth was 30 . Table 3 gives a summary of geotechnical parameters used in the analyses. $\mathrm{D}_{50}$ values were reported to range between $0.12 \mathrm{~mm}$ and $1.8 \mathrm{~mm}$. Thus, an average $\mathrm{D}_{50}$ value of $1 \mathrm{~mm}$ was considered in analyses.
An average fine content for top $9 \mathrm{~m}$ was taken as $20 \%$ based on the data shown in Fig. 9. The ground water table was assumed at $1 \mathrm{~m}$ depth in liquefaction analyses as the areas, where liquefaction was observed were near the Lake Van and potentially had very shallow ground water table.

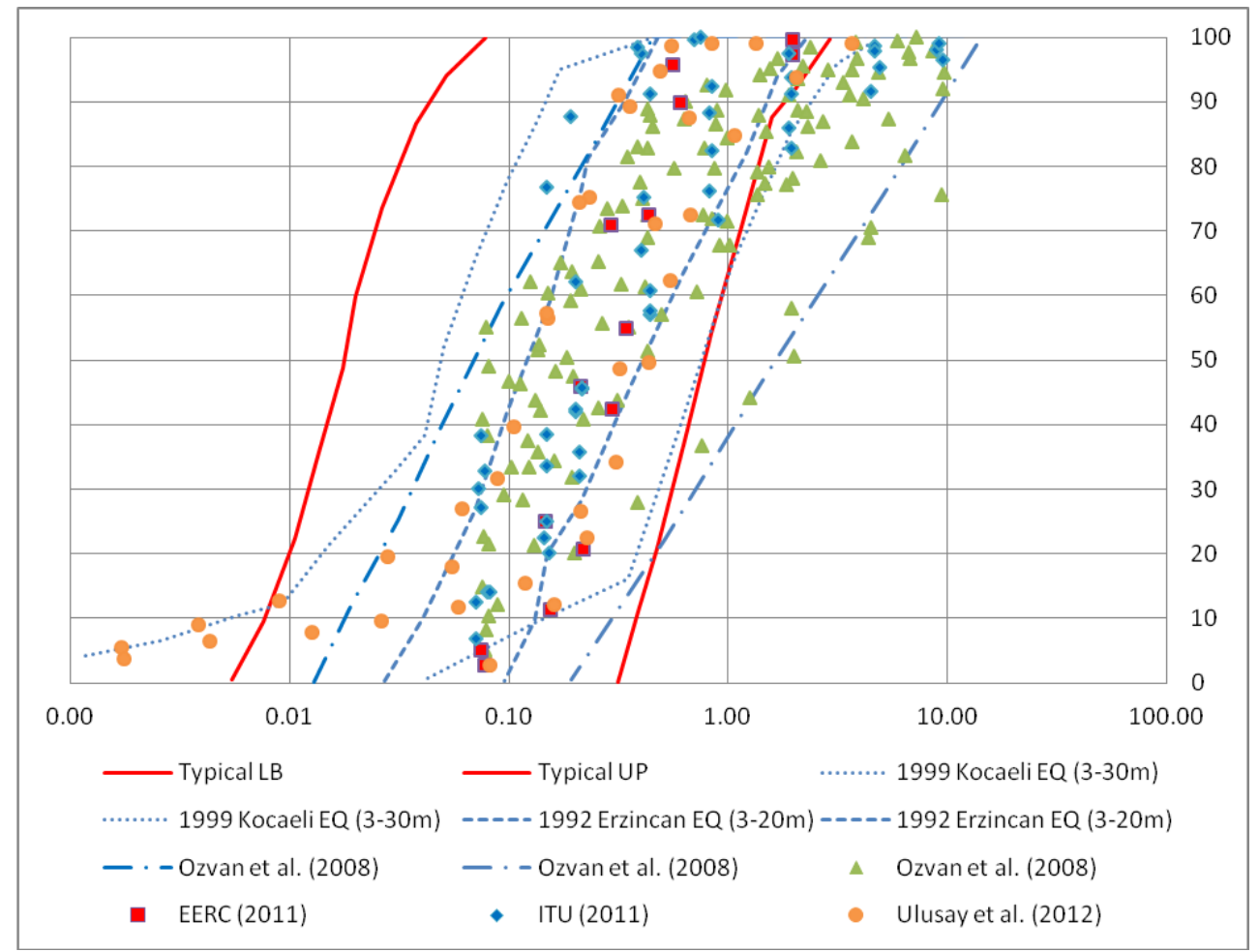

Fig. 9 Grain size distribution of the liquefiable materials of Ercis Plain

Table 3 Soil layers considered in the analyses

\begin{tabular}{|c|c|c|c|c|c|}
\hline Layer & $\begin{array}{l}\text { Unit Weight } \\
\left(\mathbf{k N} / \mathbf{m}^{3}\right)\end{array}$ & $\begin{array}{c}\text { Fine Content } \\
(\%)\end{array}$ & $\begin{array}{c}\text { Thickness } \\
\text { (m) }\end{array}$ & $\begin{array}{c}\text { Average } \\
\left(\mathbf{N}_{1}\right)_{60}\end{array}$ & $\begin{array}{l}\text { Average }{ }^{\dagger} \\
\text { Vs }(\mathbf{m} / \mathbf{s})\end{array}$ \\
\hline Layer 1 & 16 & 20 & 9 & 15 & 220 \\
\hline Layer $2^{*}$ & 17 & N/A & 21 & 30 & 350 \\
\hline
\end{tabular}

${ }^{*}$ Layer 2 was not considered in liquefaction assessment. ${ }^{\dagger}$ SPT correlation in Bellana (2009) was used in $\mathrm{V}_{\mathrm{s}}$ estimates.

\subsection{Analytical methods used in evaluation}

The safety factors against liquefaction triggering and soil lateral spreading were evaluated using various methodologies outlined below. The site specific ground response analyses were conducted using 1D wave propagation analysis software DEEPSOIL (V6, University of Illinois at Urbana-Champaign, 2015). A frequency domain analysis procedure was adopted. Cyclic Stress Ratio (CSR) values were calculated using site specific ground response analyses and compared to the soil Cyclic Resistance Ratio (CRR) to calculate the safety factor against liquefaction.

The liquefaction potential was performed using Cyclic Stress Ratio (CSR) values obtained from the site specific ground response analyses as well as simplified approach proposed by Seed and Idriss (1971). Equations 1 to 3 provide the calculation procedure for the factor of safety (FoS), i.e. 


$$
\begin{aligned}
& F O S=\frac{C R R}{C S R} * K_{\sigma} * K \\
& C R R_{7.5}=C R R * M S F \\
& M S F=\left(\frac{7.5}{\mathrm{M}}\right)^{2.56}
\end{aligned}
$$

where, $K_{\sigma}$ is the overburden stress correction factor, $\mathrm{K}$ the sloping ground correction factor, $\mathrm{M}$ the earthquake magnitude and MSF a magnitude correction factor.

CRR values used in the assessment were determined using various methods. The simplified stratigraphy used in the assessment was depicted in Table 3.

\section{Cyclic stress ratio (CSR)}

Maximum cyclic shear stresses ratios obtained from the free-field response analyses as well as simplified approach proposed by Seed and Idriss (1971) were used for the assessment.

\section{Cyclic resistance ratio (CRR)}

The CRR values were evaluated using various SPT based methods, as summarized in Table 4. The average CRR values were utilized for the calculation of FoS against liquefaction triggering. Only the top layer $(9 \mathrm{~m})$ was considered in the liquefaction evaluation. Layer 2 was deemed unlikely to liquefy due to its high stiffness (Vs = $350 \mathrm{~m} / \mathrm{s}$ ) and was not considered in the assessment.

Table 4 CRR evaluation methods

\begin{tabular}{l}
\hline \multicolumn{1}{c}{ Method of Analysis } \\
\hline Vancouver Task Force Report (2007) Method \\
\hline NCEER Workshop (1997) Method \\
\hline Boulanger and Idriss (2004) Method \\
\hline Japanese Highway Bridge Code Method \\
\hline Chinese Code Method \\
\hline
\end{tabular}

\section{Post-liquefaction evaluation}

The method proposed by Faris et al (2006) was used to evaluate the liquefaction induced lateral soil spreading that would take place during the design earthquake. This method is based on
Displacement Potential Index (DPI) that is calculated using CSR values. Liquefaction induced soil settlements were calculated using the method proposed by Ishihara and Yoshimi (1992).

\section{Results and Discussion}

\subsection{Site specific ground response analyses}

The results of site specific ground response analyses are summarized in Table 5. The analyses showed that the applied input ground motion $(\mathrm{N}$ $\mathrm{S}$ component of Muradiye record) was amplified. The maximum amplification factor was calculated as 2.1. Figure 10 shows the acceleration time history of the ground response at the ground surface. The Cyclic Stress Ratio for the liquefiable layer (Layer 1) was calculated as 0.5. This value was used in liquefaction assessments.

Table 5 Results of site specific ground response analyses

\begin{tabular}{ccc}
\hline $\begin{array}{c}\text { Max. } \\
\text { Acceleration (g) }\end{array}$ & $\begin{array}{c}\text { Amplification } \\
\text { Factor }\end{array}$ & CSR \\
\hline & 0.38 & 2.1 \\
\hline \\
\hline 0.30 \\
0.20 \\
0.10
\end{tabular}

Fig. 10 Acceleration time history at the ground surface

\subsection{Assessment of liquefaction}

The CRR values were calculated and depicted in Fig. 11 using the five different methods outlined in Table 4. The results in Fig. 11 depict that the average CRR values were slightly above 2 except for Japanese Highway Bridge Code approach, which yielded to slightly higher values of CRR. The FoS against liquefaction triggering was calculated using the average values of the CRR and CSR obtained from site specific ground 


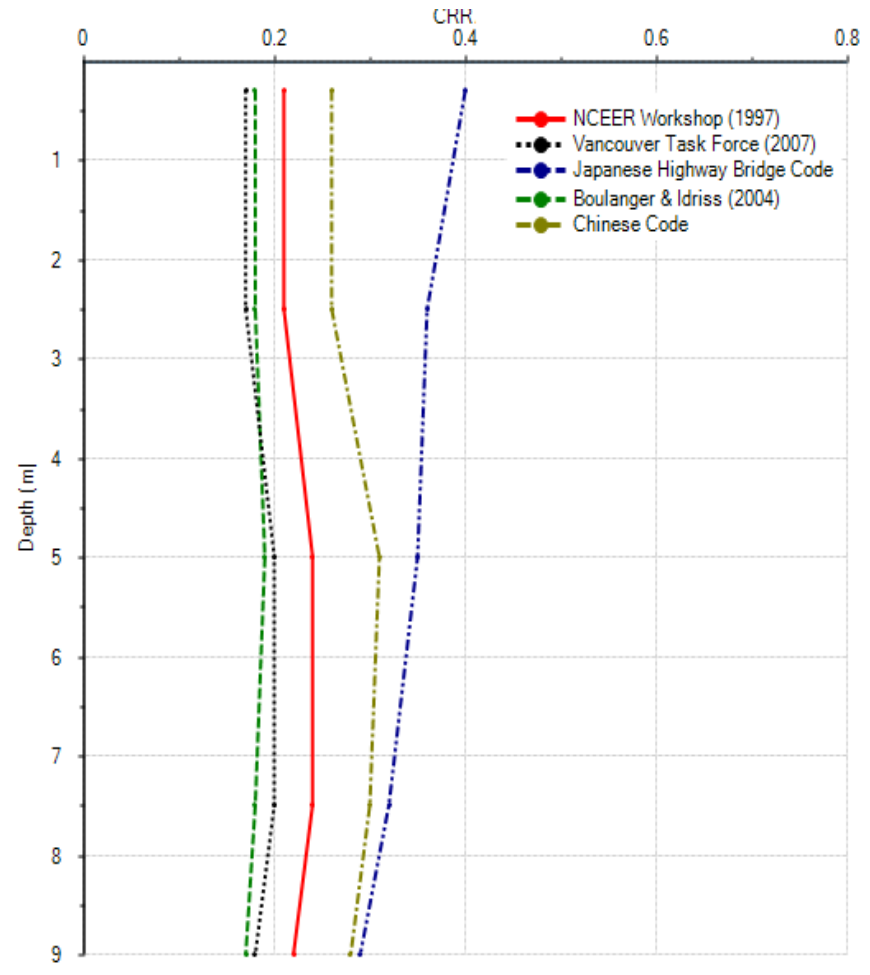

Fig. 11 CRR profiles calculated using various analytical approaches

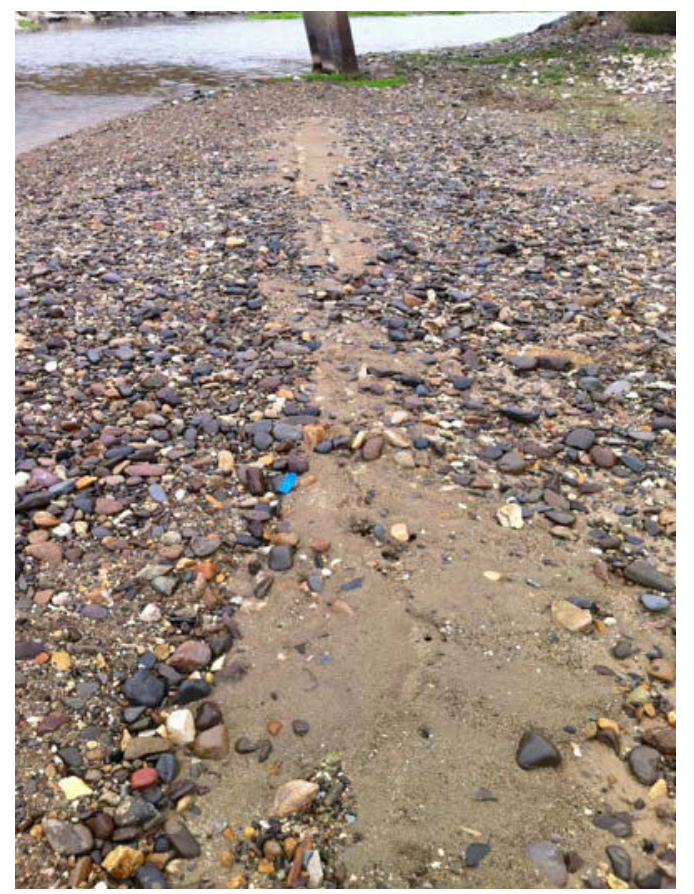

Fig. 12 Sand boiling in Zilan River (after Cetin et al. 2011)

response analyses and from simplified method of Seed and Idriss (1971). A FoS of 0.55 was calculated against liquefaction triggering using the CSR values obtained from site specific ground response analyses, which indicates occurrence of liquefaction. The liquefaction induced ground settlement was calculated as 100 $\mathrm{mm}$ in accordance with Ishihara and Yoshimi (1992). Using the analytical approach proposed by Faris et al (2006), lateral spreading of $600 \mathrm{~mm}$ was estimated.

Post earthquake field observations indicated that pockets of the area investigated have experienced liquefaction. Despite the difficulty of quantifying the liquefaction induced ground movement (the area was a constructed zone), signs of lateral soil movement as well as foundation settlements in some buildings were observed. Since the liquefaction assessment presented in this study was based on an average of SPT profiles that were considered to be representative of the area, it is expected that some locations with higher SPT $\mathrm{N}$ values did not experience liquefaction. This explains the localized nature of observed liquefaction. Namely, only the locations with low SPT $\mathrm{N}$ values were thought to have liquefied during the earthquake. Figure 12 shows the sand boiling that occurred near Zilan River.

\section{Summary and Conclusions}

The analysis of seismic induced liquefactions that took place in and around Ercis Township, where Irsat and Zilan streams are discharged to Lake Van, was performed using various analytical methods commonly used in engineering practice. The dynamic soil properties were estimated using correlations with available SPT profiles and incorporated into site specific ground response analyses to establish the cyclic stress ratios. The results of these analyses were used in the liquefaction assessment and estimation of seismic induced settlements as well as lateral spreading that were observed in Ercis Plain. The results were compared to qualitative field observations, and the following conclusions are derived:

- The predicted liquefaction using the simple analytical approach in Ercis Plain is supported by field observations.

- The one dimensional seismic ground response analyses performed on simplified ground stratigraphy indicate that the input ground motion (Muradiye Record N-S component) used at the bottom of soil column was amplified 2.1 times, 
resulting in a maximum $\mathrm{CSR}=0.5$ at the midheight of the liquefiable layer (Layer 1).

- The liquefaction-induced settlement and lateral soil spreading are estimated as $100 \mathrm{~mm}$ and 600 $\mathrm{mm}$, respectively. Signs of settlement and lateral soil spreading in that area in the ranges of the estimated values were observed in the field but exact magnitudes of these movements could not be verified with field measurements.

- The results indicate that simplified SPT based approached combined with site specific ground response analyses is an effective tool for estimating liquefaction occurrence as well as the magnitudes of vertical and horizontal soil deformations.

\section{Acknowledgements}

The authors acknowledge the valuable contributions by the reviewers and the support provided by the Material Engineering and Research Office of the Ontario Ministry of Transportation, and Dr. Ali Ozvan.

\section{References}

Acarlar, M., E. Bilgin, E. Elibol, T. Erkal and İ. Gedik, 1991. The geology of eastern and northern of Van Lake. General Directorate of MTA No: 1061 (in Turkish).

Akyüz, S., C. Zabcı and T. Sançar, 2011. Preliminary report about 23 ekim 2011 Van earthquake. Special Report, İstanbul Techncal University, İstanbul, Turkey (in Turkish).

Ashour, M. and G. Norris, 2003. Lateral loaded pile response in liquefied soil. J. Geotech. Geoenviron. Eng., ASCE 129(6): 404 - 414.

Barka, A. and K. Kadinsky-Cade, 1988. Strikeslip fault geometry in Turkey and its influence on earthquake activity. Tectonics, 7(3):663-684.

Bellana, N., 2009. Shear wave velocity as function of SPT penetration resistance and vertical effective stress at california bridge sites. Dissertation, University of California, Los Angeles.

Cakar, S., 2010. The geotechnical problems stemming from soil properties and their solutions for Van province and nearby places. Graduation project, Yuzuncu Yil University, Van, Turkey (in Turkish).
Ceken, U., T. Kuru, A. Apak, D. Kökbudak, E. Tepeuğur, H. Albayrak, V. Özsaraç, S. Sezer and C. Şahin, 2011. The evaluation of strong groundmotion records of 23 ekim 2011 Van earthquake. AFAD, Special Report. (in Turkish).

Cetin, K.O., M. Turkoglu, S.O. Oral and U. Nacar, 2011. Van-tabanlı earthquake $(\mathrm{mw}=$ 7.1) October 23, 2011. Preliminary reconnaissance report, Middle East Technical University, Earthquake Engineering Research Center, Ankara, Turkey.

Dewey, J.F., M.R. Hempton, W.S.F. Kidd, F. Şaroğlu and A.M.C. Şengör, 1986. Shortening of continental lithosphere: the neotectonics of Eastern Anatolia - a young collision zone. Geol. Soc. Spec. Publ., 19: 1 - 36.

Dewey, J.F. and A.M.C. Şengör, 1979. Aegean and surroundings regions: complex multiplate and continuum tectonics in a convergent zone. Geolog. Soc. of Amer. Bull., 90(1): 84 - 92.

Dhont, D. and J. Chorowicz, 2006. Review of the neotectonics of the Eastern TurkishArmenian Plateau by geomorphic analysis of digital elevation model imagery. International Journal of Earth Sciences, 95(1): 34 - 49.

Faris, A.T., R.B. Seed, R.E. Kayen and J. Wu, 2006. A semi-empirical model for the estimation of maximum horizontal displacement due to liquefaction-induced lateral spreading. Proc. of 8th National Conference on Earthquake Engineering, EERI, San Francisco.

Finn, W.D.L. and N. Fujita, 2002. Piles in liquefiable soils: seismic analysis and design issues. Soil Dynamics and Earthquake Engineering, 22(9): 731 - 742.

Hempton, M.R., 1985. Structure and morphology of the East Anatolian Transform fault zone near Lake Hazar, southeastern Turkey. Geol. Soc. of Amer. Bull., 96: 233 - 243.

Ishihara, K., 1993. Liquefaction and flow failure during earthquakes. Geotechnique, 43(3): 351415.

Ishihara, K. and M. Yoshimine, 1992. Evaluation of settlements in sand deposits following liquefaction during earthquakes. Soils and Foundations, 32(1): 173 - 188.

Jackson, J. A. and D. McKenzie D, 1988. The 
relationship between plate motions and seismic moment tensors, and the rates of active deformation in the Mediterranean and Middle East. Geophys. J. Int., 93(1): 45 - 73.

Koçyiğit, A., Yılmaz, A., Adamia, S., Kuloshvili, S., 2001. Neotectonics of East Anotolian Plateau (Turkey) and Lesser Caucasus: Implication for Transition from Thrusting to Strike-Slip Faulting. Geodinamica Acta, 14: 177-195.

Liu, L. and R. Dobry, 1995. Effect of liquefaction on lateral response of piles by centrifuge model tests. NCEER report to FHWA. NCEER Bulletin, 9(1): 7 - 11.

McKenzie, D., 1976. The East Anatolian Fault: a major structure in eastern Turkey. Earth Planet Sci. Lett., 29(1): 189 - 193.

METU/EERC, 2011. Field observations on the seismic and structural damages for October 23 2011 Mw 7.2 Van earthquake. Special Report. Middle East Technical University, Earthquake Engineering Research Center, Ankara, Turkey (in Turkish).

MTA, 2002. Geological maps of Turkey, Van map section. General Directorate of MTA, Ankara, Turkey (in Turkish).

McClusky, S., S. Balassanian, A. Barka, C. Demir, S. Ergintav, I. Georgiev, O. Gurkan, M. Hamburger, K. Hurst, H. Kahle, K. Kastens, G. Kekelidze, R. King, V. Kotzev, O. Lenk, S. Mahmoud, A. Mishin, M. Nadariya, A. Ouzounis, D. Paradissis, Y. Peter, M. Prilepin, R. Reilinger, I. Sanli, H. Seeger, A. Tealeb, M.N. Toksoz and G. Veis, 2000. GPS constraints on plate motion and deformation in the eastern Mediterranean: implications for plate dynamics. Journal of Geophysical Research, 105: 5695 - 719.

Türkelli, N., E. Sandvol, E. Zor, R. Gok, T. Bekler, A. Al-Lazki, H. Karabulut, S. Kuleli, T. Eken, C. Gurbuz, S. Bayraktutan, B. Seber and M. Barazangi, 2003. Seismogenic zones in Eastern Turkey. Geophysical Research Letters, 30(24): 8039.

Norris, G., R. Siddharthan, Z. Zafir and R. Madhu, 1997. Liquefaction and residual strength of sands from drained triaxial tests. J. Geotech. Geoenviron. Eng., ASCE 123(3): $220-228$.

Özvan, A., M.A. Şengül and M. Tapan M, 2008. An overview of geotechnical characteristics of
Neogene sediments of Van Lake basin: Erciş site. Geosound, 52: 297 - 310 (in Turkish).

Pearce, J.A., J.F. Bender, S.E. De Long, W.S.F. Kidd, P.J. Low, Y. Guner, F. Saroglu, Y. Yilmaz, S. Moorbath and J.G. Mitchell, 1990. Genesis of collision volcanism in Eastern Anatolia, Turkey. Journal of Volcanology and Geothermal Research, 44(1-2): 189 - 229.

Rollins, K.M., T.M. Gerber, L.J. Dusty and S.A. Ashford, 2005. Lateral resistance of a fullscale pile group in liquefied sand. Journal of Geotechnical and Geoenvironmental Engineering, ASCE 131(1): 115 - 125.

Rotstein, Y. and A.L. Kafka, 1982. Seismotectonics of the southern boundary of Anatolia, Eastern Mediterranean region: subduction, collision, and arc jumping. J. Geophys. Res., 87(B9): 7694 - 7706.

Şaroğlu, F. and Y. Y1lmaz, 1986. Geological evolution and basin models at Eastern Anatolia in the Neotectonic period. General Directorate of MTA, Department of geological research, Ankara (in Turkish).

Seed, H.B. and I.M. Idriss, 1971. Simplified procedure for evaluating soil liquefaction potential. J. Geotech. Eng. Div., ASCE 97(9): 1249 - 1273.

Şengör, A.M.C. and W.S.F. Kidd, 1979. Postcollisional tectonics of the Turkish Iranian plateau and a comparison with Tibet. Tectonophysics, 55(3-4): 361 - 376.

Şengör, A.M.C. and Y. Y1lmaz, 1983. Evolution of Tethys in Turkey: An approximation in terms of plate tectonic. Turkey Geological Society Special Series of Geosciences, no.1, İstanbul (in Turkish).

TMMOB-JMO, 2011. Van (Tabanli-Edremit) depremleri raporu. Special Report., Turkey (in Turkish).

Ulusay, R., H. Kumsar, K. Konagai and O. Aydan, 2012. The characteristics of geotechnical damage by the 2011 Van-Erciş earthquake. Proc. of the int'l symposium on engineering lessons learned from the 2011 Great East Japan Earthquake, Tokyo, Japan.

Yılmaz, Y., F. Şaroğlu and Y. Güner, 1987. Initiation of the neomagmatism in East Anatolia. Tectonophysics, 134(1-3): 177 - 199. 